\title{
LIUDKEVYCH AND ZEMLINSKYI: A TYPOLOGICAL COMPARISON OF TEACHER AND STUDENT
}

Liubov Kyianovska ${ }^{12}$, Vasyl Fedoryshyn ${ }^{3}$, Lidia Melnyk ${ }^{1,4}$, Alla Kozyr $r^{3,5}$

\section{ЛЮДКЕВИЧ І ЗЕМЛІНСЬКИЙ: ТИПОЛОГІЧНЕ ПОРІВНЯННЯ УЧИТЕЛЯ І УЧНЯ}

\section{Любов Кияновсъка, Василь Федоришин, Лідія Мелъник, Алла Козир}

В процесі еволюції західноукраїнської музичної культури наступає період, коли відбувається доволі різкий злам у її розвитку і вона завойовує сфери, перед тим не надто притаманні для музичного життя краю, головно камерно-інструментальні та симфонічні жанри, тяжіє до професіоналізації - на відміну від попередніх пріоритетів аматорських форм, інтенсивно інтегрується в загальноєвропейський процес на противагу до попередньої окремішньості, впевнено виходить на нові рівні трансформації національного в контексті універсального. Цей період припадає на перші десятиліття ХХ ст. і пов'язаний з діяльністю нової генерації музикантів-професіоналів, серед яких одне з провідних місць займає Станіслав Людкевич.

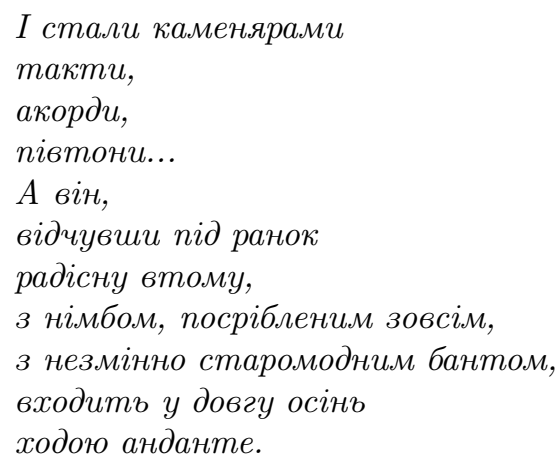

\footnotetext{
${ }^{1}$ Mykola Lysenko Lviv State Academy of Music.

2 https://orcid.org/0000-0002-0117-5078

${ }^{3}$ National Pedagogical Dragomanov University. https://orcid.org/0000-0002-0994-1910

${ }^{4}$ https://orcid.org.0000-0002-2796-5940

${ }^{5}$ https://orcid.org.0000-0003-3124-975X
} 
У цих поетичних рядках відомого українського поета-дисидента Ігоря Калинця, корінного галичанина, не просто, мов у краплині води, відбилось ставлення наших краян до своєї «музичної легенди» - композитора Станіслава Людкевича, а підсвідомо відображена також певна «несхожість», винятковість його навіть у високоталановитому, професійному і блискуче ерудованому середовищі, в якому йому довелось перебувати: коло Василя Барвінського, Нестора Нижанківського, Миколи Колесси, Зиновія Лиська, коло Романа Савицького і Юрія Криха, Лесі Деркач і Антіна Рудницького, коло десятків інших видатних музикантів, поетів, політиків, вчених Людкевич все одно завжди залишався особливою постаттю. До цього так звикли, що дослідники практично не звертають на його оригінальність спеціальної уваги, акцентуючи більше те, що він зрушив у рутині провінційного життя, в чому став аніматором, аналізують його творчість, діяльність тощо. А однак багато що і в його творчості, і в музично-теоретичній спадщині не пояснюється тільки національною традицією, тільки тією місією, яку він для себе обрав і блискуче виконав, чи тільки вродженими рисами натури. I в цьому місці неминуче постає питання про вплив вчителів, про спадкоємність головних естетичних і творчих засад певної школи, в якій митець сформувався як професіонал і мистецька особистість.

В тому сенсі представникам т. зв. «львівської празької школи» пощастило дещо більше, бо Празька консерваторія і Вітезслав Новак як їх спільна alma mater і патрон, розглядались уважніше і були краще знані, зв'язок інтересів учителя і учнів підкреслювався ними всіма і усно, і письмово, в ряді статей та спогадів. Зрештою з'явилась узагальнююча стаття Стефанії Павлишин [1, с. 17], в якій докладно простежується зв'язок Новака $з$ його львівськими учнями. Відень, неймовірно притягальний центр для молодої західноукраїнської інтелігенції, особливо ж наприкінці XIX в перших десятиріччях XX ст., де навчались, творили і виступали численні українські мистці, в тому числі музиканти, не отримав такого уважного вивчення у вітчизняному музикознавстві, таким чином, варто звернути увагу на цю напрочуд перспективну для дослідників музики тему.

Для Людкевича Відень став надзвичайно важливим осередком формування як загального світогляду, так і специфічно музичних пріоритетів. Не без значення було й те, що він приїхав туди вже достатньо зрілою людиною, коло 30 років, після студій у Львові, маючи за плечима значний досвід культурно-просвітницької і організаційної роботи в музичному житті. Музикологічні студії у Віденському університеті в класі відомого теоретика Германа Греденера та знаменитого Гвідо Адлєра були ним усвідомлені як необхідна умова подальшої наукової і творчої праці. I цілком невипадково його докторська дисертація була присвячена проблемам етномузикознавства: «Дві проблеми розвитку звукозображальності», захищена 1907 р., вона репрезентує той напрямок дослідження генези музики, який активно розробляється в тогочасній австрійській та німецькій науці.

Але особливо істотним стало для нього навчання в класі композиції та інструментовки Олександра Землінського, де він передусім своєрідно сприйняв основні естетично-творчі засади, пануючі в той час в провідних європейських школах. Єдність національного, своєрідного та того, що геніальний Гете назвав єдиною європейською школою Weltliteratur - ось те гасло, котре накреслив Людкевич як своє естетичне кредо. I те, що його твори 
значно переростають рамки етнографічної «національної характерності», нерідко притаманної його попередникам в галицькій композиторській школі, очевидно мало певний зв'язок з його навчанням у Землінського.

На жаль, особа і творчий спадок Землінського надто мало знані українському меломанові - та й не тільки йому. Для освіченої публіки він довго залишався лише учителем Арнольда Шенберґа, майже невідомий як композитор і музичний діяч. «Ренесанс Землінського» в Австрії відбувається фактично лише з 1989 p. із заснування у Відні фонду імені композитора. В 1992-му була проведена перша масштабна конференція, присвячена творчості Землінського і організована одним із найвідоміших її дослідників, віденським музикознавцем Гартмутом Кронесом. До речі, навіть сама транскрипція прізвища композитора залишається досі неусталеною - в російській, а відтак і українській музикознавчій літературі прийнятим є прочитання «Цемлінський». Інформація про нього взагалі вкрай неповна. Скупі відомості в кількох музичних енциклопедіях, артикули в два-три речення - диригент, вчитель Шенберга, і обов'язково - «композитор-епігон пізнього романтизму» - насправді сформували хибне уявлення про постать Землінського і його значення для австрійської музичної культури зламу століть. На захист творчої спадщини Землінського, щоправда, ще в 1959 р. пробував стати Теодор Адорно, висловивши цілком правильну думку про те, що «його еклектизм є геніальним завдяки зростанню (в історичній перспективі - Л.К.) від простого сприйняття (рецептивності) до глибокого переживання» $[2$, s. 354]. Проте ці спостереження так і залишились тільки частковими поглядами вченого, не знайшовши поширення.

Не ставлячи собі за мету дати повну біографію і огляд творчості австрійського композитора, відзначимо кілька сутнісних моментів, які допоможуть опосередковано пояснити слушність порівняння «Людкевич Землінський», окреслити ті лінії перетину, які видаються доволі очевидними у світогляді обидвох мистців.

Встановлюючи походження Землінського відзначимо, що воно є достатньо багатонаціональним. Його батько, Адольф фон Земліншки, на час народження первістка й тривалий час згодом був центральною постаттю в громаді євреїв-сефардів Леопольдштадту. Попри свою активну заангажованість у життя єврейської громади Леопольдштадту, Адольф фон Цемліншки не мав єврейських коренів. Його дід, Антон Семлінськи, приїхав до Відня із рідної Польщі на початку XIX ст., як і багато поляківемігрантів на той час осів у другій дільниці (Леопольдштадт), згодом одружився із донькою віденського музиканта Цецилією Пуллєтц і відкрив власну кав'ярню. Досі невідомо, звідки в посполитого польського «малого підприємця» 3'явився в прізвищі аристократичний префікс «фон», однак у свідоцтві про хрещення (в католицькому обряді) сина Адольфа зустрічаємо вже не тільки змінену транскрипцію, але й респектабельний додаток «фон». ${ }^{1}$

У консерваторії Алєксандр фон Земліншки навчався вісім років: спершу в підготовчій школі по класу фортепіано, а згодом і в класах ком-

\footnotetext{
${ }^{1}$ Усі ці документи стали відомими дослідникам завдяки тому, що в 1938 році їх копії були представлені композитором Алєксандром фон Цемлінським для підтвердження його «арійського походження», що, однак, не врятувало музиканта: згідно із «законом про раси» він залишався на чверть євреєм, оскільки його мати була донькою євреївсефардів.
} 
позиції, гармонії, камерного ансамблю та оркестрування. Серед вчителів Землінського - такі величини як Роберт Фукс (знаменитий австрійський теоретик, учнями якого були також свого часу Густав Малєр, Гуго Вольф, Франц Шрекер, Ян Сібеліус, Джордже Енеску), його брат Йоганн Непомук Фукс - учитель Землінського в класі композиції та Франц Кренн (в класі якого Землінський вивчав контрапункт). Віденська консерваторія залишалася на зламі століть своєрідним форпостом музичного академізму, виховуючи в той же час музикантів та композиторів найрізноманітніших напрямків та уподобань. I власне Землінський - справжнісіньке «дитя імперії» за своїм мішаним походженням, котрий виріс у небагатих єврейських кварталах, дуже гостро зумів відчути змалку різницю між метрополійним і провінційним, виявився надзвичайно сприйнятливим до цих «метрополій них», універсальних музичних студій, новітніх художніх віянь, заради яких до Відня з’їжджалися музиканти з цілої Європи.

Завершив студії в класі композиції Землінський 1892 року Симфонією ре-мінор: першим масштабним твором, у якому з однаковою силою відобразилася й солідна академічна школа, і захоплення Й. Брамсом, котрий, поруч із Р. Вагнером залишався для Землінського на той час найвизначнішим прикладом у композиції. Цікаво, що в таких уподобаннях дуже яскраво відобразилася загальна тенденція епохи, переконання нової генерації композиторів, для яких протистояння між «брамінами» і «вагнеріанцями» вже втрачало свою актуальність: вони цінували й трансформували в своїй творчості кращі здобутки обидвох. Цей погляд на пізньоромантичних антагоністів буде таким самим характерним і для Людкевича.

Протягом десяти наступних років Землінський належатиме до об'єднання австрійських композиторів, заснованого ще Брамсом, згодом, вже разом із своїм учнем, другом і швагром Арнольдом Шенбергом заснує власне композиторське об'єднання. Як не дивно, але достатньо інтравертивного на перший погляд, стриманого і замкненого Землінського завжди приваблювала музично-громадська діяльність. Землінський залишався на позиціях пізнього романтизму, котрий, щоправда, набував у його музиці все більше рис панівного на той час у Відні сецесіону.

Хоча Землінський ніколи не провадив послідовної педагогічної діяльності в стінах консерваторії чи університету, в ньго майже постійно утримувався цілий своєрідний «клас» - можливо, навіть правильніше сказати «школа». «Він був вродженим педагогом»,- писала Альма Малєр. Хоча, на відміну від авторитарного Шенберга ніколи не диктував учням переробки творів і на перший погляд не мав особливої системи виховання. Як пригадував Станіслав Людкевич (зі слів його вдови), заняття в Землінського полягали насамперед у здобутті великого слухового досвіду він рекомендував учням окремі концерти, а найчастіше й сам відвідував ïx разом із ними, вказуючи на варті уваги фрагменти, знахідки, технічні особливості виконуваних творів. Сповідуючи до кінця життя пізньоромантичні ідеали, Землінський однак ніколи не нав'язував їх своїм вихованцям, поважаючи над усе їх власну інвенцію й креативність. Лише в окремих випадках він вказував на технічні недосконалості демонстрованих йому творів (невипадково залишаючись одним із кращих вихованців віденської академічної системи).

Станіслав Людкевич навчався, чи правильніше сказати - консультувався у Землінського протягом 1908 року, під час своїх студій у Відні. 
До речі, український композитор стилістично був одним із найближчих своєму австрійському вчителеві: їх ріднила захопленість барвистістю пізньоромантичних гармоній, особлива увага до виразного просторового звучання, багатство оркестрової палітри. Людкевич до кінця життя охоче пригадував про своє спілкування із Землінським у Відні (в той час, як наприклад про Арнольда Шенберга говорити страшенно не любив).

Біографія Землінського, починаючи від 1911 р., - постійні мандрівки в пошуках стабільності: практика диригента в Празі ${ }^{1}$, потім знову повернення до Відня, врешті вимушена еміграція до США через претензії до його єврейського «чверть походження», смерть у вигнанні і забутті... Життя одного з найбільш плідних австрійських мистців початку XX ст. завершилось у цілковитій пустці, так, як і довгі роки ігнорувалась його творчість. А однак вона дуже цікава і багатогранна, в контексті сучасного розвитку музичної культури зовсім не сприймається «старомодно», про що свідчить закономірний інтерес до його музики, який спалахнув останніми роками і призвів до видання компакт-дисків його кращих творів, в першу чергу камерно-інструментальних творів, пісень, а також численних опер, як «Флорентійський купець», «Діва озера», «Одяг творить людину», «Це було одного разу», «Крейдяне коло», «Карлик» та інші.

Що зближує Землінського та Людкевича як особистостей і дозволяє проводити типологічні паралелі: відзначена у Землінського інтравертивність натури, яка зумовлювала небажання пристосовуватись до обставин всупереч своїм переконанням (так, ніколи Землінський не зміг полюбити оперету, хоча йому довелось кілька років тільки $\dddot{11}$ і диригувати, ніколи Людкевич не похвалив твору, який йому не сподобався, а навіть не вмів приховати свого істинного ставлення), абсолютну принциповість у відстоюванні своїх ідеалів, а разом з тим постійна потреба громадської діяльності, організації угрупувань, об'єднань, проведення акцій, висловлювання своїх думок на сторінках преси, що більше свідчить про натуру екстравертивну. Але ця суперечливість швидше позірна: вона відображає незламну переконаність у важливості своєї місії, абсолютну відданість тій вищій меті, яку кожен з них для себе поставив, що змушувало відсікати їх все другорядне, неістотне у своєму житті і максимально використовувати всі соціальні важелі для реалізації поставленого завдання. Окреслення «лицар без страху і докору» однаково пасує їм обом ${ }^{2}$.

Якщо шукати принципової спільності в їх індивідуальній композиторській манері (чи швидше естетичному світогляді, що вплинув на вибір стильових моделей), то одразу впадає у вічі послідовне дотримання пізньоромантичної стилістики, своєрідне перевтілення водночас вагнеріанства і брамсіанства. Пригадаймо, що в усій західноукраїнській культурі лише Людкевич трансформував певні індивідуальні стильові засади «байройтського генія» ${ }^{3}$, представники «празької школи» більше тяжіли до ім-

\footnotetext{
${ }^{1}$ Де його в 1928 р. слухав ще один видатний львівський мистець Микола Колесса (відомості, безпосередньо від нього почуті).

2 Такими самими максималістами видаються і деякі інші пізні романтики, як Вагнер чи Малєр, однак у них ця відданість мистецтву помножена ще на крайній егоцентризм, потребу за будь-яку ціну бути в центрі уваги суспільства, оточеним любов'ю, поклонінням і увагою, займати найвищі щаблі у музичній ієрархії. Цієї риси як Землінський, так і Людкевич були позбавлені.

${ }^{3}$ Про це див. численні публікації автора, зокрема: Стильова еволюція галицької музичної культури XIX-XX ст. - Тернопіль: Астон, 2000. - Розд. 3; Вплив австронімецької культури на формування стилю Станіслава Людкевича // Матеріали між-
} 
пресіонізму та неофольклоризму. Водночас і вплив Брамса помітний в ряді вокальних творів Людкевича, а навіть постулюється ним у фортепіанній п'єсі «Тихий вечір» на тему Брамса. Як вказує дослідниця фортепіанного стилю Людкевича Г. Блажкевич, Брамс йому найбільше близький «насиченістю фортепіанної фактури полімелодизмом, багатоплановістю фактурного розшарування, розкішною пізньо-романтичною гармонічною мовою» $[3$, с. 86]. Ці ознаки цілком очевидно помічаються і в камерних вокальних та інструментальних творах Землінського.

У обидвох мистців вірність пізньоромантичним ідеалам зберігалась практично протягом усього життя всупереч новішим тенденціям, хоча це нерідко призводило до несприйняття, а то й критики (особливо у випадку Землінського) їх опусів. Проте ніякі зовнішні переваги не могли змусити їх змінити свої внутрішні переконання.

Друге, що їх об'єднує, це потреба багатогранної музичної діяльності, яка б не просто доповнювала композиторську творчість, а постійно інспірувала, спрямовувала її. Землінський був одним 3 кращих європейських диригентів свого часу, про що свідчить навіть такий вибагливий і іронічний музикант, як Ігор Стравінський: «Я гадаю, що з усіх диригентів, яких я чув, я б обрав Землінського як найвидатнішого диригента, який відповідає найвищим вимогам: і це зріле судження» [4]. Людкевич став одним з найбільш фундаментальних українських фольклористів і музикознавців першої половини XX ст. Ця паралельна мистецька сфера дуже сильно обумовлювала композиторські пошуки їх обох: немало творів Землінського виникало завдяки його диригентській праці (наприклад, опери, які він став писати, отримавши грунтовну практику у віденських театрах), Людкевич часто немовби ілюструє (ясна річ, підсвідомо) ті тези, які містяться у його естетико-теоретичних розвідках. Наприклад, опосередковане втілення національного первня в його масштабних творах досконало пояснюється в статтях, зокрема «Націоналізм в музиці» «Переймання чужих форм... $\epsilon$ конечною умовою розвою всіх народів, особливо ж опізнених у розвою, воно не тільки не занапащувало народних елементів, але доводило до скорішого їх культурного сформування» [5, с. 140]. Зрештою, такий підхід теж $є$ вельми типовим для (пізнього) романтизму з його автобіографічними колізіями і вже значно менше характерний для пізніших генерацій, хоча б для раціональних пріоритетів композиторів міжвоєнного двадцятиріччя.

Третє, що притаманне їм обидвом, це схильність до масштабності, багатства та розкоші оркестровки, гармонії, прекрасне відчуття звукової барви і простору, розбудованість мелодичної фрази, а також колосальне відчуття слова, своєрідна літературність музичного мислення. Постульований романтиками синтез мистецтв, який у XX ст. нерідко сприймається із значною долею іронії, для них залишається неодмінною умовою творчого процесу. I хоча в обох не бракує інструментальних творів, позбавлених програмного імпульсу (більше у Землінського, значно менше - у Людкевича), проте навіть в них відчувається та ж орієнтація на фабульні колізії, на єдність конкретного і узагальненого, яка так приваблює у виразовій системі доби романтизму. Разом з тим певна «перебринілість» романтичних

народного симпозіуму «Українсько-німецькі музичні зв'язки минулого і сьогодення». Київ, 1998. - С. 67-77; Еволюція стилю Станіслава Людкевича у європейському контексті // Питання стилю і форми в музиці. В серї: «аукові збірки ЛДМА ім. М. Лисенка». Вип. 4. - Львів: Каменяр, 2001. - С. 80-90 та ін. 
ідеалів змушує їх шукати більш відсторонений, філософсько-заглиблений ракурс «образу слова»в музиці.

Отже, навіть стисле типологічне порівняння вчителя й учня, Землінського і Людкевича, дозволяє зробити кілька висновків: по-перше, не просто про інтенсивність європейської інтеграції західноукраїнських композиторів у перших десятиріччях XX ст., а про вельми успішні пошуки індивідуальних шляхів цієї інтеграції, які кожному з блискучої генерації «священичих дітей» дозволив сягнути висот мистецьких відкриттів. Подруге, про природність міжнаціональних контактів українських музикантів, особливо ж в час, коли нова генерація сміливо утверджує європейські орієнтири національної культури. За слушним спостереженням Оксани Забужко, «це покоління здатне було вже на автентично українському культурному грунті ставити питання про «європеїзацію» психологічної домінанти українства».[6, с.116] По-третє - загально значимий погляд на спілкування вчителя і учня, про ту величезну відповідальність педагога перед своєю місією, який дає багато підстав для роздумів: можливо, якщо Людкевичу не так пощастило з учителем, щось трохи б змінилось в нашій музичній культурі?

\section{Література}

[1] Павлишин С. 1997. Львівські музиканти та «Празька Школа. Союз Українсъких Професійнх Музик у Лъвові: матеріали і документи». Львів.

[2] Theodor W. 1978. Adorno. Zemlinsky. Quasi una fantasia. Gesammelte Schriften 16. Frankfurt am Main.

[3] Брилинська-Блажкевич Г. 1991. Фортепіанна творчість С. Людкевича: дис. канд. іст. наук., Київ.

[4] Igor Strawinsky. 1964. On Conductors and Conducting. Show, August.

[5] Людкевич С. 1973. Дослідження, статі, рецензії. Київ.

[6] Забужко, О. 1992. Філософія української ідеї та європейський контекст. Франківський період. Київ, Либідь.

\section{References}

[1] Pavlyshyn S. 1997. Lvivski muzykanty ta «Prazka Shkola. Soiuz Ukrainskykh Profesiinykh Muzyk u Lvovi : materialy i dokumenty». Lviv.

[2] Theodor W. 1978. Adorno. Zemlinsky. Quasi una fantasia. Gesammelte Schriften 16. Frankfurt am Main.

[3] Brylynska-Blazhkevych H. 1991. Fortepianna tvorchist S. Liudkevycha: dys. kand. ist. nauk, Kyiv.

[4] Igor Strawinsky. 1964. On Conductors and Conducting. Show, August.

[5] Liudkevych S. 1973. Doslidzhennia, stati, retsenzii. Kyiv, S. 140.

[6] Zabuzhko, O. 1992. Filosofiia ukrainskoi idei ta yevropeiskyi kontekst. Frankivskyi period. Kyiv. Lybid. 